\title{
TEACHING MORALITY: JAVANESE ISLAMIC EDUCATION IN A GLOBALIZING ERA ${ }^{1}$
}

\author{
Ronald A. Lukens-Bull
}

\section{UNIVERSITY OF NORTH FLORIDA, JACKSONVILLE}

\begin{abstract}
As Indonesia strives to overcome its position as a periphery nation, its populations are faced with increasing challenges to traditional identity and morality. With economic development comes a great exposure to global consumer culture. This paper examines how traditionalist Muslims in Java, Indonesia, are facing the perceived impact of globalization through educational efforts and the re-invention of tradition. A key institution in this process is the Islamic boarding school called pesantren. Pesantren curriculum has become a focal point in the strategy of the traditionalist community to encounter globalization. By shaping curriculum, pesantren leaders are trying to mold future generations of Indonesian leaders and citizens. The goal is to create a society that is fully modern, fully globalized, fully Indonesian, and fully Islamic, one student at a time. In this process, both modernity and tradition are re-invented in such a way that one cannot exist without the other.
\end{abstract}

In July 1995, Yusuf Hashim, the eldest surviving son of Haidratus Syahk Hashim Ashari told me why he had led Tebu Ireng, the Islamic boarding "seminary" (J, I: pesantren) founded by his father, toward a more secular

1 This paper is based on research funded by an Henry Luce Foundation/Arizona State University Southeast Asia Dissertation Fellowship. An earlier version was presented at the 1998 American Anthropological Association Meetings in Philadelphia, PA. The author would also like to thank the following people for their insights and comments: Joseph Bell, Kenneth George, Susan Jungk, Katryne Lukens-Bull, and Mark Woodward.

Indonesian and Javanese words are spelled according to the official conventions set in 1972. The major changes were $\mathrm{dj}=\mathrm{j}$ (as in John); $\mathrm{j}=\mathrm{y}$ (as in yes); $\mathrm{tj}=\mathrm{c}$ (as in choke); oe $=u$. The only exceptions to this are words within quotes, titles of books published before 1972, and the proper names of authors and major figures. Arabic words will be spelled according to accepted English transliteration, a modified version of the systems of the Library of Congress and the Encyclopaedia of Islam. Arabic names of Indonesian persons and organizations will be spelled according to Indonesian conventions. Where Indonesian usage differs markedly from the Arabic, I will use the Indonesian form. 
curriculum. He likened these changes to those found in public transportation; the Ford Rose was replaced by the Mitsubishi Colt, which in turn was replaced by a Suzuki mini-van. Each was more competitive than its predecessor both in purchase price and in operation costs. He argued that noncompetitive pesantren will likewise be driven out of the market; parents will not send their children to schools that do not help them obtain employment in an increasingly technologically and scientifically based society.

While acknowledging the need for pesantren to be competitive, Yusuf Hashim recounted the story of Harvard University as a cautionary tale. As he explains, Harvard began as a religious institution, but has since lost its religious character. He warns that such must not be allowed to happen with pesantren. While the schools add new subjects and adopt new forms of education, their religious character and that of their graduates must not be sacrificed. Yusuf Hashim's concern with offering an education that is competitive in a modernizing and globalizing society while maintaining a solid religious base is mirrored in many of the 1800 pesantren found in East Java and the other 2200 found elsewhere in Indonesia. Yusuf Hashim and his counterparts are making assertions about the nature of society, Islam, and modernization, and acting on them.

This paper will place Yusuf Hashim's concerns within the context of his peers and the Islamic community in Indonesia as well as in the context of wider social processes to explore issues surrounding globalization and modernization. In Java, and Indonesia in general, education has been a central component of modernization. John Bowen affirms that schools are important loci in the transformation of sentiments and loyalties in Southeast Asia. "Schools," he argues, "have long been reckoned by political scientists to be a primary place for 'modernization'; yet we know very little of what transpires in school." While most of the learning is content oriented, the students learn new ways of interacting with others and with themselves, and develop "precisely those attitudes toward time, work, and society that led modernization theorists of the 1950s to hope that schools would "make men modern"" (Bowen 1996, 1058-59). However, Bowen overlooks schools like pesantren, which offer both state curricula and other lessons and thereby strive to make people modern, but in a particular mode.

Pesantren, which resemble the madrasa (A: religious school) elsewhere in the Islamic world, seem to have been of some interest to Western scholars (Anderson 1990, 64-65, 127-28, Denny 1995, Geertz 1960a, 180-87, 1960b, Jones 1991), certain works having been published in Indonesian (Steenbrink 1974, Van Bruinessen 1995). Indonesian scholars, on the other 
hand, have produced an enormous literature on them, including countless books and scholarly theses. Most of this literature is firmly based on the work of Zamakhsyari Dhofier (1980, 1982, 1999) and Taufik Abdullah (1987), which remain good introductions to the study of these schools. A large number of these works assert that pesantren and modernity are not incompatible but can work together for the betterment of the nation (see especially, Galba 1991, Prasodjo et al. 1974, Yacub 1985). Others argue, perhaps more accurately, that the exact role of pesantren is still being debated (Abdullah 1987).

This paper uses ethnographic data to explore some of the ways in which the traditionalist Islamic community in Indonesia uses pesantren education as part of its strategy for encountering globalization and modernization. By shaping the curriculum in pesantren, pesantren people are shaping the identity of both the Indonesian Islamic community and Indonesia itself. They are inventing "modernity" and remaking it in an Islamic and an Indonesian mold. The data used here is placed in the theoretical context of globalization in general, and more specifically, in the context of Muslim encounters with it. After describing methodological approaches, this paper describes the broad contexts in which the data should be considered, and then, for the bulk of the paper, analyzes the data in detail.

\section{Research Setting and Methods}

The argument presented here is based on ethnographic fieldwork conducted in 1994-95 which took a regional rather than a village-based approach. As Bowen has suggested, the texts and rituals of Islam take the believer, and should take the ethnographer, outside the village to a "worldwide confessional community" (1993, 185). A regional study allows us to explain processes beyond the boundaries of a single village. However, this is still a limited view and does not encompass the whole Islamic world. While such are the limitations of any fieldwork, the processes discussed here are part of larger processes in Indonesia and the Islamic world in general.

Whereas this research speaks to wider Indonesian society, and even to Muslim societies in general, it was conducted in East Java, which is the recognized center of the pesantren world; many prominent leaders of the Islamic community, both traditionalists and modernists come from East Java. Approximately 1,800 of the more than 4,000 pesantren in Indonesia are found in East Java (Ghofir et al., 1982, ii). The pesantren selected for research were typical of those that are engaged in the on-going process of defining and redefining pesantren education. Extended ethnographic research was conducted in three pesantren: Tebu Ireng in Jombang, An-Nur II in the Kabupaten (I: Regency) of Malang, and Al-Hikam in the city of 
Malang.

Tebu Ireng has about 1,500 students, all male, but it is part of a complex of family pesantren that includes pesantren for female students, some of whom attend the government curriculum schools in Tebu Ireng. Tebu Ireng gives a slight emphasis to government curricula over traditional pesantren education. It has a rich history that is intertwined with that of the Republic of Indonesia. Tebu Ireng's founder, Hasyim Asyari was a co-founder of Nahdlatul Ulama (NU), the largest Islamic organization in Indonesia, and several of his descendants, including Abdurrahman Wahid (then Chair of Nahdlatul Ulama, now President of Indonesia), have played and continue to play important roles in the Indonesian public sphere. This national range of influence is reflected in the fact that Tebu Ireng's students come from all over Indonesia. Further, the grave of its founder, in the heart of the school, is an important pilgrimage site that draws several thousand visitors each month. In addition to my own efforts, a number of Indonesian scholars have written about Tebu Ireng (e.g., Dhofier 1980, Arifin 1993).

An-Nur II has about 500 students, mostly from East Java and mostly male (it had 19 female students in 1995). However, it is also part of a larger complex of family run pesantren that includes another 1,000 students, 300 of whom are female. An-Nur has a history of less than 50 years and is run by the sons of the founder. While both government and religious education is offered at An-Nur, the focus is decidedly on the traditional pesantren curriculum. The range of influence of An-Nur and its leadership is mainly limited to the area around Malang, as evidenced by the fact that nearly half of its students come from this area.

Al-Hikam is the newest of the three pesantren discussed in this paper. In 1995, it was just three years old and had 60 male students. It differs from both Tebu Ireng and An-Nur in several ways. First, it did not grow out of a traditional pesantren, but was designed as a place where college students can engage in traditional pesantren education and mysticism while pursuing their college degrees. All of the students attend college in Malang and most are from East Java. The headmaster, Hasyim Muzadi is the head of NU East Java, and a khalif (A, I: deputy) in the Qadiri-Naqshibandiyah tarekat (I. Sufi Order; A. tarīqa).

\section{Globalization Defined}

Globalization is a term often used and seldom defined. For my purposes here, I use the term "globalization" as a cover term for the processes by which the "world capitalist system" becomes articulated with local systems. Others have looked at the articulation of global systems with local systems 
(Smith 1984), but they have focused on the economic articulation, how the colonial structure of metropole-satellite (core-periphery) was reproduced in local settings. Globalization may affect technology, economics, politics, culture, and religion. Various authors have looked at aspects of globalization under the names modernization and Westernization (c.f., Ward and Rustow 1964, Inkeles and Smith 1974, Miller 1994). Westernization and modernization are labels for aspects of globalization. Because the terms are used in both Indonesian discourse and Western scholarship, their use here will reflect such usage. However, throughout they are understood to represent, at least part of, globalization, or the process by which local cultures become part of the flows of commodities, images, ideas, ideologies, and people that characterize late global capitalism. Anthony Giddens avers that capitalism is a driving force in globalization because it is primarily an economic order and secondarily involves cultural and political matters (1990).

Daniel Miller remarks that Jürgen Habermas sees modernity as a product of the juxtaposition of three events: the Renaissance, the Reformation, and the discovery of the New World $(1994,61)$. The three key events mentioned above all occurred around the early sixteenth century, roughly the same time period to which Wallerstein attributes the beginning of the world capitalist system (1974). For this reason, modernity can be seen as part and parcel of globalization, that is, the process by which capitalism expands itself.

Modernity, to Habermas, is essentially a mode of thought that refuses to accept tradition without reflection and reevaluation. He states, "modernity can and will no longer borrow the criteria by which it takes its orientation from the models supplied by another epoch; it has to create its normativity out of itself' (1987, 7). Clearly this mode of thought is linked to scientific method and is precisely the mechanism by which the adoption of scientific technology may challenge other aspects of social and cultural life. Habermas seems to suggest that modernity necessarily challenges and ultimately replaces tradition. The material considered here suggests otherwise.

In discussing the cultural impacts of globalization on local cultures, Westernization refers to a particular kind of culture change that follows an imagined model of Western life. Westernization is often conflated with modernization:

To escape anomy (sic), Muslims have but one choice, for modernization requires Westernization. . . . Islam does not offer an alternative way to modernize. . . . Secularism cannot be avoided. Modern science and technology require an absorption of the thought processes which accompany them; so too with political institutions. Because content must be emulated no less than form, the predominance of Western civilization must be acknowledged so as to be able to learn from it. European lan- 
guage and Western educational institutions cannot be avoided, even if the latter do encourage freethinking and easy living. Only when Muslims explicitly accept the Western model will they be in a position to technicalize and then to develop. (Pipes 1983, 197-98)

While Pipes' cultural chauvinism is extraordinary, he does raise an important question: Can Muslims adopt the technology of the West and still hold fast to the teachings of the Prophet? Or are the values of the West (and Westernization itself) inseparable from Western technology and Western style education. The conflation of modernization and Westernization also occurs in Indonesian discourse. There are those who believe that modernization can only come about by imitating Western, particularly American, cultural practices. In short, some Indonesians, and even some Muslims, seem to agree with Pipes.

In his consideration of the modern movement of commodities and images, Arjun Appadurai argues:

Globalization does not necessarily or even frequently imply homogenization or Americanization, and to the extent that different societies appropriate the materials of modernity differently, there is still ample room for the deep study of specific geographies, histories, and languages. $(1996,17)$

Hence, the major contribution of this paper is to explore the specificities of how the Indonesian traditionalist Muslim community appropriates the materials of modernity. In this appropriation, the leaders of this community are concerned with the deleterious effects of modernization, as they see them-egotism, materialism, social inequities. Further, it explores how, despite Appadurai's claim above, these leaders see the negative aspects of modernity as essentially the Western, if not American, trimmings on the house of modernity. As part of their appropriation of the materials of modernity and their subsequent reinvention of modernity, these leaders have created an educational system both to address the educational needs of a modernizing society and, at the same time, to guard against perceived moral decay.

\section{Globalization and Java}

We will now turn to one local experience of globalization. Specifically, it concerns the perceived impact of late global capitalism on Indonesian religious values and education. Post-independence Indonesia has seen tremendous economic growth and with it an increasing trend towards the intrusion of American consumer culture, which Benjamin Barber argues will inevitably destroy all local culture and remake it into a Disneyesque theme park of 
shopping malls (1995). Many young people wear blue jeans, go to discos, and get drunk because these things are seen as "modern," "Western," and hence desirable activities.

Appadurai reminds us that "particular conjunctures of commodity flow and trade can create unpredicted changes in value structures" $(1996,72)$. This is particularly true in the arena of what he calls "mediascapes," the technologies to produce and disseminate information and the "images of the world created by these media" (1996, 35). In the early 1990s, the U.S. required Indonesia to import American films and television shows in order to continue to export textiles to the U.S. (Barber 1995, 91). Repeatedly I heard concerns from pesantren people about the American movie industry's purported intention of destroying Islam and corrupting the values of Islamic societies such as Indonesia. Many were concerned with the portrayal of scantily clad women (with bare shoulders and knees). Such concerns persist even though Appadurai asserts that "the United States is no longer the puppeteer of a world system of images but is only one node of a complex transnational construction of imaginary landscapes" (1996, 31). Appadurai acknowledges, however, that international media "afford powerful resources for countermodes of identity that youth can project against parental wishes or desires" $(1996,45)$. If no longer puppeteers, certainly the American image makers still create images of, and models for, "modernity" that must be contended with in other nations.

Many pesantren people associate the processes of modernization and globalization with the loss of traditional values. One elderly ustadh (I: low ranking Islamic teacher) at Pesantren Mahasiswa Al-Hikam lamented that Indonesia had lost its own value system:

Indonesia once had established values, as can be seen in the successful establishment of the Republic of Indonesia. These values were the values of 1945. However in the 1980s these values began to be lost and are now completely lost. The problem is that these days, young people want to be like the United States or Japan as quickly as possible. But, they often forget that Japan has held on to its values tenaciously. The Koran can guarantee life in the future, the Koran can take us back to the values of 1945.

Many kyais (J, I: high ranking Islamic teachers), ustadhs, and other pesantren people agree with this basic sentiment, that the values upon which Indonesia was established have been eroded by modernization and Westernization. Nafik, another ustadh at Al-Hikam, attributes this to people who naively link Westernization and modernization, a linkage Howard Federspiel identifies in the writings of Siradjuddin Abbas (1996, 202). Nafik argued that much of what is done in Indonesia today is Westernization 
without any real modernization. Education can overcome such naiveté and hence, he says, the goal of Al-Hikam is to train modern people (arts and sciences students) with traditional values. People so trained will be able to lead the nation so that it can engage in globalization and forge a new national identity consistent with an Islamic heritage.

Several people I interviewed asserted that giving up Islam is not necessary for modernization, but this claim itself assumes a modernity in which the spiritual is challenged. Indeed, Abdul Gani, an ustadh at pesantren An-Nur argued that "man-made religions" like Buddhism and Hinduism were incompatible with modernity. Islam on the other hand, as a revealed religion, is good for all times and can fit with modernity. However, elements of popular Islam need to be excised from the communal body of practice in order for Islamic countries to prosper. Abdul Gani identified these as aspects of popular mysticism (kepercayan) around ancestral spirits. Otherwise, he clearly supported the notion of the place of Sufism in modernity, as did many others.

Robert Bellah pointed out that modernity should be seen not 'as a form of political or economic system, but as a spiritual phenomenon or a kind of mentality' (1968). This is precisely the component of modernity with which pesantren people are most concerned. They want the technology and the political and economic dimensions of modernism, however, with respect to the mentality of modernism they wish to define an Islamic modernity. There are certain values and morals they wish to see underpin modernity. These values include Islamic brotherhood, selflessness (keikhlasan), simplicity in living (kesederhanaan), and self-sufficiency (kemandirian). Also included is a concern for social justice and serving the needs of the poor. Taken together, these values define a modernity quite different from that dominant in the West.

Bernard Lewis argues that since the sixteenth century, there have been three basic attitudes toward modernization ${ }^{2}$ and Westernization (here considered part of globalization) that Muslims might take (1997). The first is that of a supermarket: Muslims may adopt what they find useful without adopting the religion or the values of the West. He argues that this view some-

\footnotetext{
${ }^{2}$ Lewis also reminds us that in an earlier period of "modernization" (in the late Middle Ages) Europeans may have well asked "Can we adopt the technology of the Muslims and still hold fast to the teachings of Christianity?" as they adopted the Muslim innovations of experimental science, algebra, and astronomy, as well as paper, the zero, and positional numbering, which Muslims brought from China and India respectively $(1997,129)$.
} 
times comes in an extreme form "in the writings and utterances of the socalled Islamic fundamentalists, who see Western civilization, and particularly American popular culture, as immoral and dangerously corrupting" (Lewis 1997, 127). Lewis associates this position specifically with the Ayatollah Khomeini who decried the United States as the Great Satan, or the seducer of Islam. The second attitude is a hopeful one that seeks to marry the best elements of both civilizations. However, Lewis argues, more often than not the result is not a marriage of the best but "a promiscuous cohabitation of the worst" (Lewis 1997, 127). The third attitude was that that of Kemal Atatürk and the Young Turk movement; namely, that "the world has seen many civilizations. Each has grown and flourished in its day, then passed away. At this moment in history only one is still alive. We must join it or be uncivilized" (Lewis 1997, 127).

Most pesantren people are taking the second tack. However, they are doing more than simply trying to marry the best of both worlds, they are making an Islamic modernity. If modernity entails a set of attitudes about authority, time, society, politics, economics, and religion, then the leaders of the pesantren world are trying to shape those attitudes. The ultimate concern is still with salvation and the hereafter. Concerns about this world are fine as long as the hereafter is not forgotten. They are aware of the Enlightenment thesis that this world is all there is, and they consciously reject it. In the next section we will turn to specific strategies now exploited in the pesantren world. Pesantren people are redefining modernity, and because pesantren are educational institutions, a key way they are seeking to do so is through restructuring their curriculum and thereby restructuring the thoughts of approximately $30 \%$ of Indonesia's school-age children.

\section{Educational Responses to Globalization}

The Islamic boarding schools known as pesantren traditionally taught an almost exclusively religious curriculum and were the training grounds for religious leaders. Because there is no organized priesthood in Indonesian Islam, the scholars (kyai) who own, run, and teach in these schools are the leaders of the traditionalist Islamic community in Indonesia. Prior to the twentieth century, pesantren were the only form of education found in Java (Abdullah 1987, Denny 1995, 298). The court poets of both the Yogyakarta and Surakarta courts were educated in pesantren (Florida 1995), as were some members of the ruling class (Pemberton 1994, 48-49, Adas 1979). In the late nineteenth century, the Dutch introduced secular education to the ruling elite. In response to this, various nationalist organizations started secular schools as part of their nation making strategy (Anderson 1990, 132, 243). After independence, Indonesia established, as part of its nation build- 
ing strategy, a national education system which could teach the national language and the national philosophy (Pancasila) as well as educate its new citizens in science and math.

Pesantren are associated with the traditionalist community in Indonesia. Traditionalists openly reject the claims of modernists to have established pesantren, stating that the modernists have done little more that create religious boarding houses and dormitories. Pesantren people declare that the critical components of mysticism, classical texts, and character development are missing from these upstart institutions. With this censure they condemn the modernist approach to modernity.

Clifford Geertz, when writing about pesantren, and their headmasters (kyai) nearly 40 years ago, predicted that they would be crushed by modernity:

Only through the creation of a school at once as religiously satisfying to the villager as the pesantren, and as instrumentally functional to the growth of the "new Indonesia" as the state-run secular schools can the kijaji [kyai] as the teacher of such a school, become a man once more competent to stand guard "over the crucial junctures of synapses of relationship which connect the local system with the larger whole. ..." Failing this the kijaji's days as a dominant force in pious Javanese villages are numbered, and the role of Islam in shaping the direction of political evolution in Indonesia is likely to be marginal at best.

Whether or not the men actually filling the kijaji role at present in Indonesia are up to a task of socio-cultural creativity of this magnitude remains to be seenthough neither the performance of NU . . . nor the slowing down of the modernist religious reform movement since 1945, gives much cause for optimism. (1960b, 249)

Geertz was not optimistic about the ability of kyai to be brokers between Indonesian cultures and modernity. Not only have kyai contradicted Geertz's expectations, what they are engaging in is not mere brokerage; they are not just translating "modernity" to Indonesia, they are inventing an Indonesian Islamic modernity.

Although Geertz was wrong in his prognosis, his diagnosis could not have been more accurate. It was repeated more recently by a leading Indonesian scholar, Taufik Abdullah, who wrote:

Therefore the future of the pesantren will be determined by its ability to maintain its identity as an ulama dominated educational system while at the same time clarifying its role as a complementary feature of national education. $(1987,102)$

Many contemporary pesantren are now doing exactly what both Geertz and Abdullah prescribed. They are engaging in both traditional pesantren educa- 
tion and national education.

Today, there are two basic government recognized curricula, the National System (Sistem Negeri), which is mostly secular, ${ }^{3}$ and the Madrasah ${ }^{4}$ System (Sistem Madrasah). The Madrasah System was originally established because many Indonesian parents were leery of the mostly secular national schools and would not send their children to them. ${ }^{5}$ Pesantren may have neither, either, or both types of schools within their grounds. All but the most conservative pesantren have at least one. The pattern in the more conservative pesantren is for the student to fulfill the minimum national requirement before starting at the pesantren. It should be noted that the adoption of national curricula was strongly encouraged by the former Suharto regime. Nonetheless, there are enough examples of pesantren that have not adopted them to suggest that the changes were not entirely externally imposed.

In addition to the government curricula, many kyai have found it useful and desirable to offer extra courses-English and computer skills being most popular-and job skills training, such as chauffeuring, automobile repair, sewing, small business management, and welding. In part, this is in response to government programs encouraging the improvement of human resources. However, skills training is also seen as a time-honored part of pesantren education. Traditionally students did not pay for their education or lodging but worked for the kyai in exchange for their expenses. Through this work they gained some skills that they could put to use after they returned home. However this tradition has been lost, because the addition of general education has meant fewer hours in the day for religious study. Hence it is now more common for students, or their parents, to pay directly for their expenses. The

\footnotetext{
${ }^{3}$ Calling either of the two national curricula secular may be a bit confusing to readers who might expect a clear separation between church and state. The national curricula both require a minimum amount of religious training. However only 5$11 \%$ of these curricula are focused on religion. Further, the official texts for these courses favor modernist positions. Hence, in the minds of pesantren people, the distinction between pesantren education and national or "secular" education is clear.

4 The Indonesian term "madrasah" is the local usage of the Arabic "madrasa" which differs from Arabic meaning. While madrasa are pesantren-like institutions, madrasah in Indonesia are day schools that follow a government curriculum that, since 1994, includes twelve percent religious instruction. Although it is uncomfortable to have two different meanings hinge on such a small difference in spelling, we have little choice when we follow the Indonesian usage.

5 The madrasah system has three levels with decreasing levels of religious instruction (Denny 1995, 298). In 1994, the amount of religious instruction in the highest level was reduced to less than $12 \%$
} 
addition of courses of immediate practical use is thus in part to compensate for the loss of apprenticeships within the pesantren. Between the Suharto regime's Meningkatkan Kwalitas Sumber Daya Manusia (I: Improve the Quality of Human Resources) Campaign and the very real need for graduates to earn an income, a pesantren that did not address these issues, or at least claim to, quickly became unpopular.

Kyai Badruddin at An-Nur said that even with the addition of secular education, the main purpose of pesantren is to spread Islam. With the addition of secular subjects, pesantren graduates are not only able to spread and strengthen Islam, but also to take care of their own basic needs. He argued that in this time of development and change, if santri (pesantren students) are only given religious education, they will not succeed.

Besides religious education, general education, and job-oriented training, the santri receive other training, such as in budgeting their monthly allowances, which will allow them to become fiscally responsible adults. Another level of practical training is in simple living. For example, Kyai Baddrudin told me that an ascetic lifestyle in the pesantren prepares students for either prosperity or poverty. In the former, they will be compassionate; in the later, they will be content. He argued that this practical education supports Indonesian development because An-Nur graduates are self-sufficient, good citizens. They will contribute to, rather than burden, their local communities and their nation, if they: (1) have an education and therefore can support themselves; (2) can be content in poverty or in riches; (3) know and understand property ownership; and (4) will not disobey the law.

An ustadh at An-Nur, one some feel is destined to become a kyai, wrote a short essay ${ }^{6}$ that summarizes some of the values taught in pesantren:

One good goal when someone has the dream of living under the protection of Allah is to have knowledge, for oneself as well as for one's people, religion, and homeland. Therefore, Muslims must have Islamic knowledge and hold tightly to it and the bounds of religion. As the adage says,

Religion without science is blind.

Science without religion is lame.

Therefore, we must not separate the two and hold tightly to both. We must carry both on our shoulders.

We must know that now is an era of "globalization." What must we do to hold back the flood? To face that new era? We have already prepared our knowledge to

\footnotetext{
${ }^{6}$ Unpublished and undated, but typed on official pesantren letterhead. Viewed in early 1995.
} 
transform ourselves and to solve problems. Meanwhile, Western superstar performers, like Madonna, are always quickly coming forward to boast of their greatness through television, video, movies, and other amusements.

To face all this we must fight our desires because on our own we have no more restraint than a baby. One kitāb [religious text, commentary] explains that we should restrain our desire with piety. In a hadith there is the additional commentary that states, "As bad as things may get, what I fear more for you is two things: that you will follow your desires and you will have fantasies, but more that you will have fantasies about this world." It is an indignity for humans, who have reason, to become slaves to materialism. Therefore we can summarize that those who live under the protection of wealth, if they cannot set their priorities, will become slaves to that wealth.

This short epistle illustrates several key concerns. First, there is a concern that without science and technology the Islamic community will be impoverished. Of greater concern, however, is that in pursuing these things, the Indonesian Islamic community will lose its moral foundations, give into sinful desires, and becomes slaves to materialism rather than servants of God.

Pesantren values define a modernity quite different from that practiced in the West, or perhaps more properly, that which functions under the aegis of nationalism and the free-market economy. Arguably, the greatest concern pesantren people have about modernization is the threat of egoism, or the emphasis on individual gain over communal gain. The values of Islamic brotherhood and selflessness are seen as safeguards to heartless entrepreneurialism. "Simplicity in living" is a control mechanism for rampant consumerism and, with the emergence of credit cards, a way to avoid the financial morass in which many Europeans and Americans find themselves. "Selfsufficiency" gives both the individual and the nation continued independence. For individuals, it means that one should seek self-employment-the very entrepreneurialism that development requires, however, one controlled by Islamic values. For the nation, it means avoiding the kind of metropolesatellite relationship that André Gunder-Frank maintains creates underdevelopment (1966).

In a lesson about modernity, Gus ${ }^{7}$ Ishom of Tebu Ireng taught one of his grandfather Hashim Ashari's texts which stated that Muslims should not adapt the ways of the käfir (A: unbelievers). In particular, one should avoid their clothing style. In part this is because the clothes (i.e., pants) may violate modesty laws, but also because wearing Western clothes symbolizes

\footnotetext{
${ }^{7}$ Gus is a Javanese title that indicates that a young man is the son of a kyai. Many famous kyai may continue to be called Gus as a friendly term. This also serves as a reminder of his pedigree.
} 
agreement with all that is Western. In the lesson it was maintained that even that young children should not be allowed to wear käfir clothes but should be trained to wear peci and sarong (I: cap and wrapped cloth, local Islamic garments). The concern, hence, is less with clothing per se, than with the construction of identity in the public sphere. In the colonial period, when the text was written, this teaching was important because it marked clear distinctions between the pesantren world and the Dutch colonizers and their collaborators. Today, Ishom's concern continues to be with public statements of separation, and hence identity. This is seen in his allowance of wearing western clothing as lounge wear in the privacy of one's home. Interestingly, this is the opposite of a common pattern in Indonesia today, the sarong and peci being worn at home while western garments are favored in public.

Gus Ishom's selection of this particular Hashim Ashari text was a commentary on contemporary issues; it was a warning about how to deal with modernity and how to avoid being trapped in the ways of unbelief. Gus Ishom was not advocating the avoidance of modernity (as symbolized in the wearing of jeans and tee-shirts), but rather the use of caution regarding it. As his students emphasized, if one's nīya (A: intention) is to be like the käfir in thought, act, and deed, then adopting Western ways is wrong. If one's niya is pure then such cultural borrowings are not a problem.

It should be noted that Gus Ishom's lesson on the dangers of modernity did not follow a purely traditional instructional method. After he read the text in Arabic and gave the makna (I: meaning) in Javanese, he explained it in Indonesian. The teacher's use of Indonesian reveals that this lesson and this text were thought of not as provincial, but rather as national, in their scope and relevance.

\section{Teaching Traditional Morality and Globalization}

Pesantren leaders today are ultimately concerned with imparting "traditional morality" to students who will participate in, and even lead, Indonesia in modernization and globalization. This morality is taught in lessons called ngaji, which involve the teaching of an Arabic text. However, ngaji is the only the beginning of moral education. Many pesantren teachers (kyai and ustadh) that I talked with pointed out that students might be able to learn the same theoretical and theological material at religious day schools near their homes. However, pesantren teachers stress that while such day schools can teach students about religion and morality, they cannot teach them to be moral. Moral education, in the sense of teaching moral behavior, must have experience, or pengalaman, at its center. Pesantren strive to create an environment in which the morals of religion can be practiced as well as studied. 
The students learn about them in ngaji and are given the opportunity to practice them. For example, communal sholat ( $\mathrm{I}<\mathrm{A}$ : worship or ritual prayer), while not required by Islam, is valued as a better way, and is generally required in pesantren. Leaders say that this practice teaches brotherhood and community, values that the Islamic community needs in order to thrive.

Other values, such as ikhlās (A, I: selflessness) ${ }^{8}$ and kesederhanaan (I: modest living) are taught by Spartan and communal living arrangements (cf. 1995, 298). In most pesantren, the santri sleep on the floor in a room that may hold up to eighty other students. A room that one might judge to be adequate for one, perhaps two students, houses six to eight; the more popular the pesantren, the more crowded the space. The meals are meager: rice and vegetables. Further, while there is an acknowledgment of personal property, in practice, property is communal. Simple things such a sandals are borrowed freely. Other items, if not in use, should be lent if asked for. The santri who habitually refuses to lend his property will be sanctioned by his peers and sometimes by the pesantren staff. I was expected to follow these guidelines as well, and I often found my tape recorder and camera missing. They were always returned later, the camera with all of its film used and with a request to have the film developed. For the santri who does not share, sanctions may include teasing or a stern reminder about Islamic brotherhood and the importance of ikhlāss.

In many ways, the details of pesantren lifestyle have not changed much over time. Given the changes of lifestyle and standard of living in the general population, however, there is a greater gap between the two, and hence the pesantren lifestyle becomes more ascetic. In other words, the simple lifestyle was once a matter of necessity, neither student nor kyai could afford more. But now enforced poverty and austerity is part of an invented pesantren tradition (cf. Hobsbawm and Ranger 1983). Indeed, many modernist schools calling themselves pesantren are criticized for being far too comfortable. As an invented, or re-invented, tradition, the ascetic lifestyle in pesantren has come to be an essential part of their character development strategy.

The value of kemandirian (self-sufficiency) is taught by having the santri take care of their own basic needs. The essential idea of this value (mandiri) is seen in a common joke. I was told repeatedly, in the presence of very young santri (six to seven years of age), that mandiri, the root of kemandirian, was an abbreviation for mandi sendiri (I: bathe on your own).

\footnotetext{
${ }^{8}$ Reflecting the Arabic nuances of purity, devotion, and faithfulness. Cf. L. Gardet, Encyclopaedia of Islam, new ed., vol. 3, s.v. "ikhlāṣ."
} 
While this joke was always met with great hilarity, it communicates quite clearly, both to the young santri (who may still be used to bathing with older siblings) and to the foreign researcher, that taking care of oneself is an important value. In traditional pesantren, mandiri manifests itself in cooking arrangements; students cooked for themselves, or in small cooperative groups. Today, to regain time for ngaji lost to general education, many pesantren employ a cafeteria system. However, santri still learn self-sufficiency through doing their own washing, ironing, and housekeeping. Again, what was once necessity has become tradition. With mandiri, however, some of the practices of the invented tradition must be dropped for practical reasons (i.e., food preparation). Hence, core elements are extracted and emphasized in other ways.

Other rules in place in most pesantren have to do with non-attendance of lessons or communal prayer, sneaking out of the compound, watching movies, theft, and other activities deemed to be against pesantren values. Most violations result in the santri receiving stern advice (nasehat). Repeated violations may bring more stern discipline. One ustadh suggested that the punishment for minor offenses such as watching movies might include beatings or even being ordered to do push-ups in sewage runoff. If the violation is greater, the student's hair may be shaved off, often just before a scheduled "parents' day" event, which will humiliate the santri. Offending students may also be sent home. Ultimately, the form and force of the discipline is at the kyai's discretion.

Gus Ishom of Tebu Ireng argues that in order to plant values (menanamkan nilai), instruction is not as important as setting a good example. In order to teach his santri the importance of sholat jama $\bar{a}^{c} a$ (communal worship) a kyai needs to lead the prayers (mengimam), not always, but often. Gus Ishom's cousin, President Abdurrahman Wahid (then general chairman of Nahdlatul Ulama) agrees that the living example of the kyai is critical in teaching santri. In this regard, Wahid points to his uncle Yusuf Hashim, who never teaches classical texts, but who does teach his students the importance of science and technology by his activities outside the pesantren, which allow him to bring government ministers to visit (there is a place for helicopters to land next to the campus for this very purpose). However, he is just as concerned about the morality of his santri as was his father (Hashim Ashari); while Hashim Ashari was concerned over the impact of popular music, Yusuf Hashim is concerned about the influence of television on santri, and has curtailed viewing considerably.

Mustahin, also at Tebu Ireng, argued that like the Prophet, the kyai should 
be an example to his students, so that pesantren education will inculcate not only religious knowledge but also moral character. Mustahin referred to the practice of the Companions in Medina, who lived together with the Prophet and witnessed the revelation of the Koran. In this context, they were able to study not only religious knowledge, but also how the Prophet actualized his faith. In like manner, a kyai must live in the pesantren so that he can set an example of an Islamic lifestyle. If he does not provide this example, then the education is instruction (pengajaran) only and not true teaching (pendidikan). In this way, Mustahin suggests, the personality and the character of the kyai himself is a central part of pesantren education.

Gus Ishom said that tasawwuf (A: mysticism, Sufism) is central in moral education. He explained that in Islam there is a "triangle" of major "sciences": tawhìd (A: theology; especially as regards the nature of Allah), fiqh (A: religious law), and tasawwuf. Each of these sciences makes different contributions. Tawhìd establishes the basis of faith. Because faith is not enough and needs "good works" $\left(a^{c} m \bar{a} l\right)$ to actualize it, fiqh provides the believers with guidelines on how to live right and perform good works. Since because good works, alone, are empty if the motivation is impure, tasawwuf is needed to instill moral and ethical values in believers. The association of Sufism and ethics as it appears in the Indonesian pesantren may be traced to a single highly influential Islamic thinker, namely al-Ghazālī. AlGhazālī is famous for his sober mysticism, which balanced theology and tașawwuf, and for his extensive works on ethics (Abdul Quasem 1975). It is through the use and study of al-Ghazālī's works that many in the pesantren world associate mysticism and ethics.

If schools make people modern, then pesantren leaders are seeking to make people modern in a distinctly Islamic way. The combination of religious training, character development, and secular education is designed to create people who can live and compete in a changing world and maintain traditional values.

\section{Conclusion}

In summary, pesantren in order to fulfill their role as educational institutions which aspire to complement secular education with madrasa subjects, offer in principle both the government curriculum and traditional religious topics. For most kyai, an additional component is critical, and that is character development. By providing secular education, religious instruction, and training aimed at character development, pesantren are creating a new type of modern Indonesian, one whose values are firmly rooted in Islamic teaching. Kyai are not merely changing the curriculum of their schools in order to compete. They are redefining modernity in an Islamic mode. Whereas our 
current theories about globalization and modernization focus on response, and thereby depict non-Western cultures as passive or reactionary, the material considered here shows that we must consider that the "receiving" peoples themselves may be restructuring the global processes. That is to say, in each local setting it may not be just the response to modernity that is localized, but also that "modernity" is re-created differently in each setting.

Religious education, in any faith, has as a central goal the teaching of tradition, however invented, and the creation young men and women who will uphold that tradition in settings that may be antagonistic towards it. As I reflect on the material considered here, I am reminded of my personal encounters with religious education as a youth. Countless Sunday School teachers and a handful of Christian college educators all had broad hopes that their efforts would mold my character in their image and that I would uphold, perpetuate, and spread their version of Christian traditions. It is hard to evaluate the actual outcome of such educational efforts. I am neither the preacher nor the missionary that some of my teachers hoped for. Nor would some of them continue to count me as a member of their fold. However, it would be impossible either to negate or neglect their impact on my character. Likewise, when we think on the character development efforts of pesantren teachers, we must not limit our assessment of those efforts to the degree to which their graduates observe the pillars of Islam, or even to the degree to which they avoid particular sins. The impact of religious education on individuals, and hence on society as a whole, is uneven, varied, and fluctuating.

Schools that combine religious and secular instruction, whether they be at the primary, secondary, or tertiary level, all have similar goals and strategies. Like religious education in general, these institutions seek to create young men and women who will "keep the faith," "walk the talk," or as said in pesantren circles "menjalakan ibadah" (I: exercise the pillars of faith). Many pesantren and American Christian colleges had their beginnings as seminaries. Both types of institutions found a growing demand for a broader, secular, and scientific education, in addition to religious instruction. The goal of these schools is invariably to train people to work in their chosen profession and through that profession realize the founding goals of the institution, namely, to spread the ideals of the faith and thereby transform society.

The experiences of other Islamic countries seem to suggest that pesantrenlike institutions (madrasas) that are unable to combine both religious and secular education will, as Geertz predicted, be relegated to the sidelines (1960b). One thing is clear, when madrasa schools fail to meet their educa- 
tional goals, for whatever reason, there are serious implications for society as a whole stemming from the resulting imbalance. In Turkey, a strong division between religious education and secular education has overtaxed the public education system leading to $27 \%$ of girls being uneducated (Mater 1996, 1997). Iran's madrasa system, as described by Mottahedeh (1985), bears a strong resemblance to the traditional pesantren system. Iran, however like Turkey, has kept secular education and madrasa education separate. It is from an exclusively religious system that the Ayatollah Khomeini emerged (Mottahedeh 1985). In contrast to both Geertz's (1960b) expectations and the examples just mentioned, the pesantren in Java have succeeded in creating a hybrid system of education combining religious instruction and scientific and technical training. This hybrid system is a reflection of a different Islamic model of interacting with modernity than that which is encountered many other places in the Islamic world. 


\section{REFERENCES}

Abdul Quasem, Muhammad. 1975. The Ethics of Al-Ghazālī: A Composite Ethics in Islam. Selangor, Malaysia: Muhammad Abdul Quasem.

Abdullah, Taufik. 1987. "The Pesantren in Historical Perspective." In Islam and Society in Southeast Asia, ed. Taufik Abdullah and Sharon Siddique. Singapore: Institute of Southeast Asian Studies.

Adas, Michael. 1979. Prophets of Rebellion: Millenarian Protest Movements against the European Colonial Order. New York: Cambridge University Press.

Anderson, Benedict. 1990. Language and Power: Exploring Political Cultures in Indonesia. Ithaca: Cornell University Press.

Appadurai, Arjun. 1996. Modernity at Large: Cultural Dimensions of Globalization. Minneapolis: University of Minnesota Press.

Arifin, Imron. 1993. Kepemimpinan Kyai: Kasus Pondok Pesantren Tebu Ireng (Kyai Leadership: The Case of Pesantren Tebu Ireng). Malang: Kalimasahada Press.

Barber, Benjamin. 1995. Jihad Vs. McWorld. New York: Times Books.

Bellah, Robert. 1968. "Meaning and Modernisation." Religious Studies 4:37-45.

Bowen, John R. 1993. "Discursive Monotheisms.” American Ethnologist 20(1):18590.

1996. "The Forms Culture Takes: A State-of-the-Field Essay on the Anthropology of Southeast Asia." The Journal of Asian Studies 54(4):1047-78.

Bruinessen, Martin van. 1995. Kitab kuning: pesantren dan tarekat: tradisi-tradisi Islam di Indonesia. Bandung: Mizan.

Denny, Frederick M. 1995. "Pesantren" Encyclopaedia of Islam, new edition, 8:296a-299a.

Dhofier, Zamakhsyari. 1980. "The Pesantren Tradition: A Study of the Role of the Kyai in the Maintenance of the Traditional Ideology of Islam in Java." Ph.D. dissertation, Anthropology, The Australian National University.

— 1982 Tradisi Pesantren: Studi tentang Pandangan Hidup Kyai (The Pesantren Tradition: A Study of the Life View of Kyai). Jakarta: LP3ES

. 1999 Pesantren Tradition: The Role of the Kyai in the Maintenance of

Traditional Islam in Java. Tempe: Arizona State University Program for Southeast Asian Studies.

Federspiel, Howard. 1996. "The Endurance of Muslim Traditionalist Scholarship: An Analysis of the Writings of the Indonesian Scholar Siradjuddin Abbas." In Toward a New Paradigm: Recent Developments in Indonesian Islamic Thought, ed. Mark Woodward. Tempe: Arizona State University Program for Southeast Asian Studies.

Florida, Nancy. 1995. Writing the Past, Inscribing the Future: History as Prophecy in Colonial Java. Durham: Duke University Press.

Frank, Andre Gunder. 1966. "The Development of Underdevelopment." In Latin 
America: Development or Revolution, 3-17

Friedman, Jonathan. 1994. Cultural Identity and Global Processes. Thousand Oaks: Sage Publications.

Galba, Sindu. 1991. Pesantren Sebagai Wasah Komunikasi (Pesantren as a Conduit of Communication). Jakarta: Departemen Pendikan dan Kebudayan.

Gardet, L. 1995. "Ikhlāṣ" Encyclopaedia of Islam, new edition, 3:1059a-60b.

Geertz, Clifford. 1960a. Religion of Java. Chicago: University of Chicago Press. 1960b. "The Javanese Kijaji: The Changing Role of a Cultural Broker." Comparative Studies in Society and History 2(2):228-49.

Ghofir, Abdul et al. 1982. Sketsa Pondok Pesantren: Laporan Hasil Studi and Eksperimentasi Pondok Pesantren di Jawa Timur (Sketch of Pesantren: Research Report on East Javanese Pesantren) Fakultas Tarbiyah IAIN Sunan Ampel: Malang.

Giddens, Anthony. 1990. The Consequences of Modernity. Cambridge: Polity Press.

Habermas, Jürgen. 1987. The Philosophical Discourse of Modernity. Cambridge: MIT Press.

Hobsbawm, Eric, and Terrance Ranger, eds. 1983. The Invention of Tradition. Cambridge: Cambridge University Press.

Inkeles, Alex and David H. Smith. 1974. Becoming Modern: Individual Change In Six Developing Countries. Cambridge: Harvard University Press.

Jones, Sidney. 1991. "The Javanese Pesantren: Between Elite and Peasantry." In Reshaping Local Worlds: Formal Education and Cultural Change in Rural Southeast Asia, ed. Charles F. Keyes. New Haven: Yale Center for International and Area Studies-Southeast Asia Studies.

Lewis, Bernard. 1997. "The West and the Middle East." Foreign Affairs 76(1):11430.

Mater, Nadire. 1996. “Turkey: High Priced Private Schools No Answer to Education Crisis.” InterPress Service English New Wire, Oct. 9, 1996.

. 1997. "Turkey: Religious Seminaries the Next Battleground for the Army." InterPress Service English New Wire, March 12, 1997.

Miller, Daniel. 1994. Modernity: An Ethnographic Approach. New York: Berg Publishers.

Mottahedeh, Roy. 1985. The Mantle of the Prophet: Religion and Politics in Iran. New York: Pantheon Books.

Pemberton, John. 1994. On the Subject of "Java.” Ithaca: Cornell University Press.

Pipes, Daniel. 1983. In the Path of God: Islam and Political Power. New York: Basic Books.

Prasodjo, Sudjoko, M. Zamroni, M. Mastuhu, Sardjono Geonari, Nurcholish Madjid, and M. Dawam Rahardo. 1974. Profil Pesantren: Laporan Hasil Penelitian Pesantren Al-Falak dan Delapan Pesantren Lain di Bogor (Pesantren Profile: A Research Report on Pesantren Al-Falak and Eight other Pesantren in Bogor). Jakarta: LP3ES.

Smith, Carol. 1984. "Local History in Global Context: Social and Economic Transitions in Western Guatemala." Comparative Studies in Society and History 26:109-33. 
Steenbrink, Karel. 1974. Pesantren, Madrasah, Sekolah. Jakarta: LP3ES.

Ward, Robert E. and Dankwart A. Rustow. 1964. Political Modernization in Japan and Turkey. Princeton, N.J.: Princeton University Press.

Wallerstein, Immanuel. 1974. The Modern World-System. I. Capitalist Agriculture and the Origins of the European World-Economy in the Sixteenth Century. Berkeley: Academic Press, Inc.

Yacub, H. M. 1985. Pondok Pesantren dan Pembangunan Masyarakat Desa (Pesantren and Development for Rural Society). Bandung: Angkasa. 